\title{
Ethnobotany and \\ Conservation of Plant \\ 署 \\ Kainji Lake National \\ Park, Nigeria
}

T.O. Amusa, S.O. Jimoh, P. Aridanzi and M. Haruna

\section{Research}

\begin{abstract}
The study was conducted to generate baseline data for the conservation and sustainable use of woody resources in Kainji Lake National Park. The study objectives were to document local knowledge on uses, status and sustainable management of selected woody species. Using both ethnobotanical and quantitative ecological methods, the study was carried out in the Borgu sector of the park. A total of 37 plants species belonging to 18 families were selected using a ranking and prioritization scale. FamilyFabaceae was the dominant family in terms of number of species represented. The species are multipurpose and are exploited to satisfy different subsistence needs. Among the plant-use categories, medicinal uses ranked highest $(38 \%)$ followed by edible plants $(25 \%)$, miscellaneous purposes $(24 \%)$, and construction (13\%). In terms of species status, Detarium microcarpum Guill. \& Perr. has the highest mean frequency of $68.9 \%$ and a population density of $3.036 \pm 1.7$ individuals/ha. This is followed by Vitellaria paradoxa C.F. Gaertn. with $55.6 \%$ mean frequency and a population density of $2.143 \pm 1.7$ individuals/ha. There was no significant relationship between the useful value of a species and its density rank $(R=0.047$; $R^{2}=0.002 ; F=0.783$ ) in the study area. Thus, the study recommends a holistic approach that includes the involvement of the local people in the management of woody species.
\end{abstract}

\section{Introduction}

According to Plotkin (2006), ethnobotany is the study of the interaction between plants and people, with a particular emphasis on traditional tribal cultures. Connie and Steven (2005) described ethnobotany as the study of how people of a particular culture and region make use of indigenous plants, and how they classify, identify and relate to them.
Today, ethnobotany is in the midst of a renaissance. This revival reflects increasing concern about the disappearance of the rain forests and other biomes of the world, and the tribal cultures inhabiting them. It is common knowledge that a plant of known economic importance to a region is often not easily destroyed when clearing for agricultural and construction purposes. However, given the unprecedented influence of human interference on the plant world at both global and local levels, the need to conserve plant genetic resources cannot be over-emphasized. This is also coupled with the need to document indigenous knowledge of plant usage and the relationships with conservation. Both the Convention on Biological Diversity (CBD 1992) and the Global Strategy for Plant Conservation and Economic Development (Twarog \& Kapoor 2004) have recognized this importance and placed a great emphasis on it.

However, indigenous knowledge of plant use is subject to numerous threats. Several economic and social factors contribute to these threats. These have been of great

\section{Correspondence}

T.O. Amusa, P. Aridanzi, M. Haruna, Federal College of Wildlife Management, Forestry Research Institute of Nigeria, P.M.B.268, New Bussa, Niger State, NIGERIA.

teejayui@yahoo.com

S.O. Jimoh, Department of Forest Resources Management, University of Ibadan, NIGERIA.

Ethnobotany Research \& Applications 8:181-194 (2010)

Published: July 01, 2010 
interest to those who believe that indigenous knowledge can contribute to the resolution of sustainability problems (Benz et al. 2000, Byers et al. 2001, Phillips \& Gentry 1993). By contrast, not all threats to the loss of indigenous knowledge among local communities are anthropogenic. Among many potential causes of loss of knowledge could be ecological, including low population size, narrow distribution ranges, introduction of non-native species, habitat loss and alteration.

Protected areas represent a valuable starting point for studying relationships between indigenous knowledge of uses of plant species and their conservation status. Kainji Lake National Park is Nigeria's oldest park established in 1976 to foster the conservation of biodiversity resources of the Kainji Lake basin and its environment. As elsewhere, many indigenous people and local communities living within the region have developed a perception and use of the natural environment in a manner that plays an important role in their livelihood strategy and the conservation of biological resources. Historically, the protected area allowed restricted access to, and use of, the area's resources by local communities who formerly were dependent on these areas for their livelihood.

In spite of the fact that there have been several attempts to document the use of plants in several indigenous communities in Nigeria, there is a dearth of empirical information describing the linkages and relationships of traditional knowledge, use patterns and plant conservation issues with regard to the availability of the species used. In this study, we investigated the uses and status of selected woody species of Kainji Lake National Park with a view to understanding the pressures faced on plant species in this protected area and to suggest measures for future conservation and management approaches.

\section{Materials and Methods}

\section{The Study area}

The study area is Kainji Lake National Park (KLNP) and the support zone communities (Figure 1). KLNP is the premier park in Nigeria covering a total area of $5340.82 \mathrm{~km}^{2}$ and composed of two non-contiguous sectors, the Borgu and Zugurma sectors. The Borgu sector with an area of $3970.02 \mathrm{~km}^{2}$ is situated in Borgu (Niger State), Kaiama and Baruten (Kwara State) Local Government areas. The Zugurma sector, on the other hand, occupies an area of $1370.80 \mathrm{~km}^{2}$ and situated in Mashegu Local Government area of Niger State. The two sectors are separated by the Kainji Lake, a lake impounded on the Niger river for hydroelectric power generation. The entire park lies between latitudes $9^{\circ} 40^{\prime} \mathrm{N}$ and $10^{\circ} 23^{\prime}$ and longitudes $3^{\circ} 30^{\prime}$ and $5^{\circ}$ 50' E (Tuna Wildlife Consultants \& NARDES 1983).
The vegetation of the Borgu sector is a transitional one between the Sudan and Northern Guinea Savanna types, while that of the Zugurma sector is typically Northern Guinea Savanna woodland (Child 1974, DRB 2004, Milligan 1979). The vegetation of the Borgu sector is differentiable by hydrological as well as soil factors into six major types viz; the Afzelia africana woodland, the Isoberlinia woodland, the Terminalia macroptera woodland, the Acacia complex, the Burkea africana / Detarium microcarpum wooded savanna and the riparian or fringing forest (Child 1974). One other distinct vegetation type of limited size is also present; this is the Diospyros mespiliformis dry forest (Figure 2).

KLNP is home to a large pool of fauna resources which include; Lion (Panthera leo L.), Bush buck (Tragelaphus scriptus Pall.), Gambia mongoose (Mungos gambianus Ogilby), Hippopotamus (Hippopotamus amphibius L.), Western hartebeest (Alcelaphus buselaphus Pall.), Nile crocodile (Crocodylus niloticus Laurenti), Grey heron (Ardea cinerea L.), Stone partridge (Ptilopachus petrosus Gmelin), Guinea fowl (Guttera pucherani Hartlaub). The park is also reputed for abundant fishery resources such as; (Labeo senegalensis Valenciennes), Nile perch (Lates niloticus L.), Moustache Catfish (Synodontis membranaceus G. Saint-Hilaire), (Alestes baremoze Joannis), Lined Citharinid (Citharinus citharus citharus G. Saint-Hilaire).

The entire study area falls into a region that can aptly be described as rural (DRB 2004). Agriculture is the most important economic activity and engages more than 75 percent of the active labour force. Besides crop production, the people of the area also engage in fishing and livestock production. Increasing population and unrestrained anthropogenic activities are impacting negatively on the rich biodiversity of the area. Illegal grazing, poaching, burning, farming, fishing and general encroachment into protected areas are human activities threatening the protection of flora and fauna in the area.

\section{Sampling}

The study was conducted from November 2005 - August 2007. Fieldwork consisted of two parts: (1) an ethnobotanical survey based on interviews; and (2) a botanical survey based on sample plots. For the ethnobotanical survey, eight communities within thirty kilometers radius of the Park in the Borgu sector were randomly selected. Household surveys using structured and semi-structured questionnaires were conducted in the selected communities. This was done using systematic sampling (every $10^{\text {th }}$ house). The respondent in each household was the head (male or female). In order to bring order and some level of precision a sampling intensity of $10 \%$ was adopted for the survey. In all 269 copies of questionnaires were administered by the research team (comprising of a female and three males). Table 1 shows the distribution of households and respondents among the communities. 
Amusa et al. - Ethnobotany and Conservation of Plant Resources of

Kainji Lake National Park, Nigeria
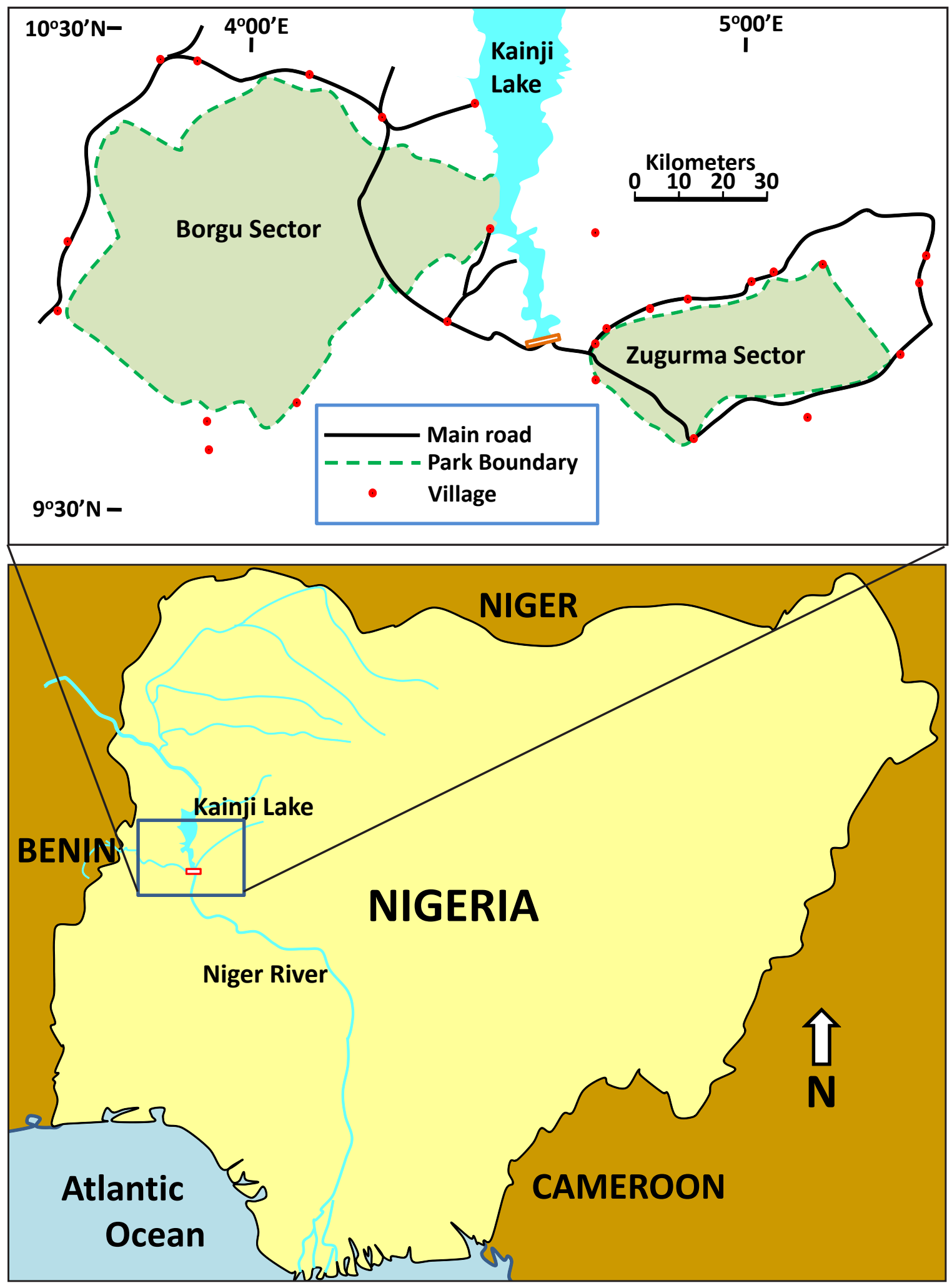

Figure 1. Kainji Lake National Park, Nigeria- Borgu and Zugurma sectors with the support zone communities. 


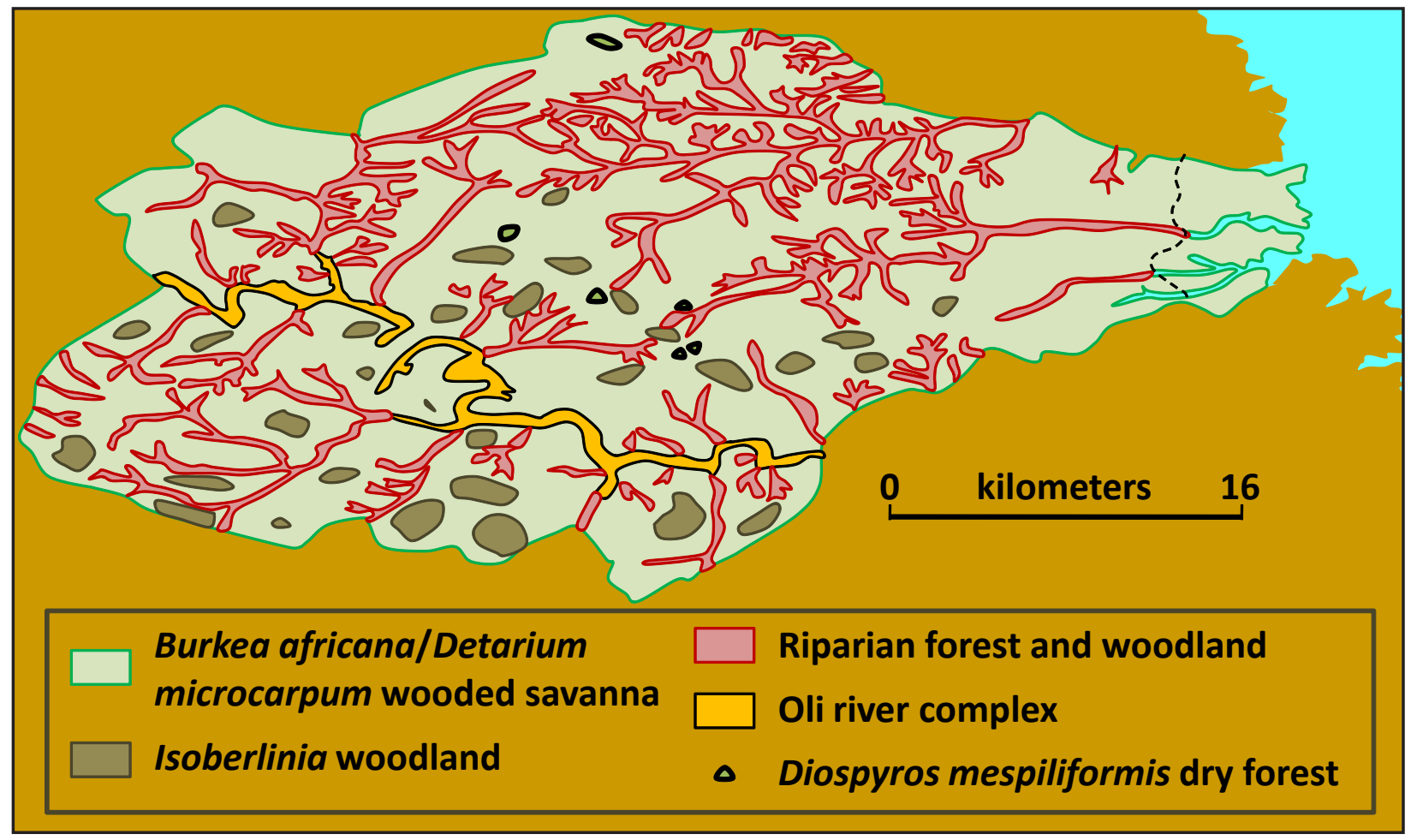

Figure 2. A generalized vegetation map of the Borgu sector, Kainji Lake National Park, Nigeria.

Table 1. Distribution of households and respondents in selected communities.

\begin{tabular}{|r|r|r|r|}
\hline Communities & $\begin{array}{l}\text { *Estimated } \\
\text { Population }\end{array}$ & $\begin{array}{l}\text { Estimated } \\
\text { number } \\
\text { of house- } \\
\text { holds }\end{array}$ & $\begin{array}{l}\text { 10\% } \\
\text { random } \\
\text { sampling }\end{array}$ \\
\hline Wawa & 6570 & 821 & 82 \\
\hline Doro & 2150 & 269 & 27 \\
\hline Luma & 1098 & 137 & 14 \\
\hline Babana & 2500 & 313 & 31 \\
\hline Kemenji & 2580 & 323 & 32 \\
\hline Duruma & 2800 & 350 & 35 \\
\hline Kuble & 1280 & 160 & 16 \\
\hline Kali & 2550 & 319 & 32 \\
\hline TOTAL & 18728 & $\mathbf{2 6 9 2}$ & $\mathbf{2 6 9}$ \\
\hline
\end{tabular}

*Data are based on the projected increase of $2.68 \%$ from the 1991 national population and house census.

We elicited additional information through focus group discussions (FGD) involving groups (male and female separately) comprising of 3-5 elders in each of the community. This medium provided opportunities for ranking and prioritization of species following Adeola et al. (1994). The species with the lowest average scores totaling 37 , were selected for detailed studies to determine their ethnobotanical and conservation status in the study area
(Table 2). Information on the different uses of each plant collected was gathered. Specifically, information on the uses of major plants of medicinal importance, their preparations and administrations (Table 3 ).

For the botanical survey, a stratified random sampling was used to select sample sites within the Borgu sector of the Park. This was done based on vegetation sub-classification as shown in Figure 2. A total of Fourteen (14) plots of $20 \mathrm{~m} \times 200 \mathrm{~m}$ strips were carefully demarcated within the selected sites. In each plot a total of ten (10) $10 \mathrm{~m} \mathrm{x}$ $10 \mathrm{~m}$ sub-plots were randomly selected for identification of plants found within each of the sub-habitat. Samples of plants collected from each of the sub-habitat were jointly identified with members of the community and taxonomists in the team using participatory rural appraisal techniques (Freudenthal \& Narrowe 1991, McCracken et al. 1998). The voucher specimens were deposited at the Forestry Herbarium Ibadan. Frequency of each species was taken as a measure of its occurrence within the sub-plots. Data collected within plots were pooled, and the mean relative frequency and population density for each plant in the study area were calculated thus;

Relative Frequency $=\frac{\text { Frequency of a species }}{\text { Sum of frequencies for all species }} \times 100$

Total number of an individual species

Population Density $=\frac{\text { from all sampled plots }}{\text { Total Area of sample plots }\left(\mathrm{m}^{2}\right)}$ 


\section{Amusa et al. - Ethnobotany and Conservation of Plant Resources of Kainji Lake National Park, Nigeria}

Table 2. Plants species studied for ethnobotanical and conservation status at Kainji Lake National Park, Nigeria.

\begin{tabular}{|c|c|c|c|}
\hline \multirow[t]{2}{*}{ Family } & \multirow[t]{2}{*}{ Species } & \multicolumn{2}{|c|}{ Vernacular Names } \\
\hline & & Bissan & Hausa \\
\hline Anacardiaceae & Lannea acida A. Rich. & & Faaru \\
\hline Annonaceae & Annona senegalensis Pers. & Moshualii & Guadar dajii \\
\hline Bignoniaceae & Kigelia africana (Lam.) Benth. & & Pahina \\
\hline Bixaceae & Cochlospermum tinctorium A. Rich. & & Rawaya \\
\hline Burseraceae & Boswellia dalzielii Hutch. & & Ararrbi \\
\hline Celastraceae & Maytenus senegalensis (Lam.) Exell & & Namijin tsada \\
\hline Chrysobalanaceae & Parinari polyandra Benth. & Blebona & Sassabani \\
\hline \multirow[t]{5}{*}{ Combretaceae } & Anogeissus leiocarpus (DC.) Guill. \& Perr. & & Marike \\
\hline & Combretum molle R. Br. ex G. Don & & Ugadamo \\
\hline & Combretum nigricans Lepr. ex Guill. \& Perr. & & Farataurania \\
\hline & Terminalia macroptera Guill. \& Perr. & & Kandari \\
\hline & Terminalia schimperiana Hochst. & Betieli & Baushe \\
\hline Ebenaceae & Diospyros mespiliformis Hochst. ex A. DC. & & Kanya \\
\hline \multirow[t]{12}{*}{ Fabaceae } & Acacia seyal Delile & & Dushe \\
\hline & Afzelia africana $\mathrm{Sm}$. & Birinlii & Kawo \\
\hline & Burkea africana Hook. & Shapatali & Kolo \\
\hline & Daniellia oliveri (Rolfe) Hutch. \& Dalziel & Birni & Maje \\
\hline & Detarium microcarpum Guill. \& Perr. & Wawalii & Taura \\
\hline & Entada africana Guill. \& Perr. & & Tawaosa \\
\hline & Isoberlinia doka Craib \& Stapf & & \\
\hline & Parkia biglobosa (Jacq.) R. Br. ex G. Don & & Doruwa \\
\hline & $\begin{array}{l}\text { Piliostigma thonningii (Schumach. } \\
\text { \& Thonn.) Milne-Redh. }\end{array}$ & Bakalali & Kalugo \\
\hline & Prosopis africana (Guill. \& Perr.) Taub. & & Kiriya \\
\hline & Pterocarpus erinaceus Poir. & & Madobia \\
\hline & Tamarindus indica L. & Tsamalii & Tsaamiyan \\
\hline Lamiaceae & Vitex doniana Sweet & Kuun & Dainyaa \\
\hline Loganiaceae & Strychnos spinosa Lam. & & Kokiya \\
\hline \multirow[t]{3}{*}{ Malvaceae } & Adansonia digitata L. & & Kuka \\
\hline & Grewia mollis Juss. & & Dargaji \\
\hline & Sterculia setigera Delile & Potcelii & Kukuki \\
\hline Meliaceae & Khaya senegalensis (Desr.) A. Juss. & & Madacii \\
\hline Olacaceae & Ximenia americana L. & & Jimikar firi \\
\hline Phyllanthaceae & Bridelia ferruginea Benth. & Daalii & Kishi \\
\hline \multirow[t]{3}{*}{ Rubiaceae } & Crossopteryx febrifuga (Afzel. ex G. Don) Benth. & Kaafiya & Kachi awaki \\
\hline & Gardenia aqualla Stapf \& Hutch. & & Gaudar dajii \\
\hline & Nauclea latifolia Sm. & Nabich biri & Kokia \\
\hline Sapotaceae & Vitellaria paradoxa C.F. Gaertn. & & Kaadanya \\
\hline
\end{tabular}


Table 3. Medicinal plants and their used studied through interviews at Kainji Lake National Park, Nigeria.

\begin{tabular}{|c|c|c|c|c|}
\hline Species & $\begin{array}{l}\text { Part } \\
\text { used }\end{array}$ & Ailment treated & Preparation & Administration \\
\hline Acacia seyal Delile & bark & $\begin{array}{l}\text { Toothache, } \\
\text { body pain }\end{array}$ & Bark is cooked alone & Fluid is drunk \\
\hline Adansonia digitata L. & bark & Toothache, cough & Bark is soaked in water & $\begin{array}{l}\text { By drinking and } \\
\text { bathing with water }\end{array}$ \\
\hline Annona senegalensis Pers. & leaf & Wounds & $\begin{array}{l}\text { Young shoots and } \\
\text { leaves are squeezed } \\
\text { to generate juice }\end{array}$ & $\begin{array}{l}\text { Juice applied on affected } \\
\text { area of wounds }\end{array}$ \\
\hline $\begin{array}{l}\text { Anogeissus leiocarpus (DC.) } \\
\text { Guill. \& Perr. }\end{array}$ & bark & $\begin{array}{l}\text { Stomachache } \\
\text { and worms }\end{array}$ & $\begin{array}{l}\text { Bark is dried, ground, } \\
\text { then boiled }\end{array}$ & Fluid is drunk \\
\hline Boswellia dalzielii Hutch. & $\begin{array}{l}\text { bark, } \\
\text { leaf }\end{array}$ & $\begin{array}{l}\text { Piles, stomach- } \\
\text { ache and worms }\end{array}$ & $\begin{array}{l}\text { Bark is dried, pounded } \\
\text { then soaked in water. } \\
\text { Leaves and bark may } \\
\text { be boiled together }\end{array}$ & $\begin{array}{l}\text { Fluid is used for } \\
\text { bathing twice a day }\end{array}$ \\
\hline Bridelia ferruginea Benth. & $\begin{array}{l}\text { root, } \\
\text { stem }\end{array}$ & $\begin{array}{l}\text { Dysentery, } \\
\text { whooping cough }\end{array}$ & $\begin{array}{l}\text { Root is cooked. } \\
\text { Stem is chewed }\end{array}$ & $\begin{array}{l}\text { Alligator pepper* } \\
\text { is inserted in the } \\
\text { stem and chewed }\end{array}$ \\
\hline Burkea africana Hook. & $\begin{array}{l}\text { leaf, } \\
\text { bark }\end{array}$ & $\begin{array}{l}\text { Stomachache, } \\
\text { body weakness } \\
\text { and joint pain }\end{array}$ & $\begin{array}{l}\text { Bark and leaves are } \\
\text { boiled together or the } \\
\text { bark is soaked alone }\end{array}$ & $\begin{array}{l}\text { Fluid is used for } \\
\text { bathing. The soaked } \\
\text { bark is drunk }\end{array}$ \\
\hline $\begin{array}{l}\text { Combretum nigricans Lepr. } \\
\text { ex Guill. \& Perr. }\end{array}$ & root & Rheumatism & $\begin{array}{l}\text { Roots are ground and } \\
\text { mixed with potash }\end{array}$ & Applied on affected area \\
\hline $\begin{array}{l}\text { Crossopteryx febrifuga } \\
\text { (Afzel. ex G. Don) Benth. }\end{array}$ & $\begin{array}{l}\text { fruit, } \\
\text { bark }\end{array}$ & $\begin{array}{l}\text { Reviving } \\
\text { domestic } \\
\text { animals; Stomach } \\
\text { disorders }\end{array}$ & $\begin{array}{l}\text { Fruit is ground and } \\
\text { mixed with potash. Bark } \\
\text { is cooked with potash }\end{array}$ & $\begin{array}{l}\text { A dying animal is } \\
\text { revived by drinking } \\
\text { this concoction }\end{array}$ \\
\hline $\begin{array}{l}\text { Daniellia oliveri (Rolfe) } \\
\text { Hutch. \& Dalziel }\end{array}$ & bark & Dysentery & Bark is soaked in water & Fluid is drunk \\
\hline $\begin{array}{l}\text { Detarium microcarpum } \\
\text { Guill. \& Perr. }\end{array}$ & $\begin{array}{l}\text { bark, } \\
\text { root, } \\
\text { leaf }\end{array}$ & $\begin{array}{l}\text { Dysentery, } \\
\text { joint pain }\end{array}$ & $\begin{array}{l}\text { Bark and roots are } \\
\text { cooked together. } \\
\text { Leaves are cooked } \\
\text { alongside other plants }\end{array}$ & $\begin{array}{l}\text { Fluid is used for bathing } \\
\text { and is also drunk }\end{array}$ \\
\hline Entada africana Guill. \& Perr. & root & $\begin{array}{l}\text { Gonorrhea, piles } \\
\text { and worms }\end{array}$ & Roots are cooked alone & Fluid is drunk \\
\hline Grewia mollis Juss. & bark & Cuts and wounds & $\begin{array}{l}\text { Bark is pounded with the } \\
\text { addition of a little water }\end{array}$ & $\begin{array}{l}\text { Applyed fresh, directly } \\
\text { on the affected area }\end{array}$ \\
\hline $\begin{array}{l}\text { Khaya senegalensis (Desr.) } \\
\text { A. Juss. }\end{array}$ & bark & $\begin{array}{l}\text { Piles and } \\
\text { stomachache }\end{array}$ & $\begin{array}{l}\text { Bark is pounded and } \\
\text { soaked in water }\end{array}$ & Fluid is drunk \\
\hline $\begin{array}{l}\text { Kigelia africana (Lam.) } \\
\text { Benth. }\end{array}$ & $\begin{array}{l}\text { root, } \\
\text { bark, } \\
\text { fruit }\end{array}$ & $\begin{array}{l}\text { Reduction of high } \\
\text { blood pressure, } \\
\text { stomach ache, } \\
\text { yellow fever }\end{array}$ & $\begin{array}{l}\text { Roots, bark and fruit } \\
\text { are peeled and cooked } \\
\text { to make a concoction }\end{array}$ & The concoction is drunk \\
\hline Lannea acida A. Rich. & bark & Blood tonic & Bark is soaked in water & Fluid is drunk daily \\
\hline $\begin{array}{l}\text { Maytenus senegalensis } \\
\text { (Lam.) Exell }\end{array}$ & $\begin{array}{l}\text { root, } \\
\text { leaf }\end{array}$ & Toothache & $\begin{array}{l}\text { Root and leaves are } \\
\text { cooked together }\end{array}$ & $\begin{array}{l}\text { Fluid is used to } \\
\text { wash mouth both } \\
\text { morning and night }\end{array}$ \\
\hline Nauclea latifolia Sm. & $\begin{array}{l}\text { root, } \\
\text { leaf }\end{array}$ & $\begin{array}{l}\text { Waist and } \\
\text { back pain }\end{array}$ & Root is boiled in water & $\begin{array}{l}\text { Fluid is used to } \\
\text { bath and drink }\end{array}$ \\
\hline
\end{tabular}


Amusa et al. - Ethnobotany and Conservation of Plant Resources of
Kainji Lake National Park, Nigeria

\begin{tabular}{|c|c|c|c|c|}
\hline Species & $\begin{array}{l}\text { Part } \\
\text { used }\end{array}$ & Ailment treated & Preparation & Administration \\
\hline Parinari polyandra Benth. & $\begin{array}{l}\text { leaf, } \\
\text { bark }\end{array}$ & $\begin{array}{l}\text { venereal disease } \\
\text { (such as syphilis) }\end{array}$ & $\begin{array}{l}\text { Leaves and bark are } \\
\text { cooked together }\end{array}$ & $\begin{array}{l}\text { Fluid drunk or } \\
\text { bark chewed }\end{array}$ \\
\hline $\begin{array}{l}\text { Parkia biglobosa (Jacq.) } \\
\text { R. Br. ex G. Don }\end{array}$ & root & Yellow fever & Root cooked with potash & Fluid is drunk \\
\hline $\begin{array}{l}\text { Piliostigma thonningii } \\
\text { (Schumach. \& Thonn.) } \\
\text { Milne-Redh. }\end{array}$ & $\begin{array}{l}\text { leaf, } \\
\text { root }\end{array}$ & $\begin{array}{l}\text { Back ache, } \\
\text { dysentery, cough } \\
\text { and piles }\end{array}$ & $\begin{array}{l}\text { Leaves and roots are } \\
\text { cooked with ginger and } \\
\text { alligator pepper* }\end{array}$ & $\begin{array}{l}\text { Bathe and drink the } \\
\text { fluid. For piles soak } \\
\text { sitting in the fluid of the } \\
\text { prepared concoction }\end{array}$ \\
\hline $\begin{array}{l}\text { Prosopis africana (Guill. } \\
\text { \& Perr.) Taub. }\end{array}$ & $\begin{array}{l}\text { leaf, } \\
\text { stem }\end{array}$ & Toothache & $\begin{array}{l}\text { Leaves and stem } \\
\text { cooked together, or } \\
\text { cut stem is chewed }\end{array}$ & $\begin{array}{l}\text { Fluid drunk or } \\
\text { stem chewed }\end{array}$ \\
\hline Pterocarpus erinaceus Poir. & bark & $\begin{array}{l}\text { Unsteady } \\
\text { menstruations, } \\
\text { blood tonic }\end{array}$ & Bark boiled with potassium & Fluid is drunk \\
\hline Sterculia setigera Delile & bark & $\begin{array}{l}\text { Increase blood } \\
\text { in the body }\end{array}$ & Bark cooked & $\begin{array}{l}\text { Fluid is drunk } \\
\text { morning and night }\end{array}$ \\
\hline Strychnos spinosa Lam. & root & Hernia & $\begin{array}{l}\text { Root dried with other } \\
\text { plant species and ground } \\
\text { into powdery form }\end{array}$ & $\begin{array}{l}\text { Mixed with pap } \\
\text { and drunk. }\end{array}$ \\
\hline Tamarindus indica L. & fruit & Ease digestion & $\begin{array}{l}\text { Fruit soaked in water } \\
\text { until dissolved }\end{array}$ & Fluid is drunk \\
\hline $\begin{array}{l}\text { Terminalia macroptera Guill. } \\
\& \text { Perr. }\end{array}$ & bark & Cough & $\begin{array}{l}\text { Bark dried, ground and } \\
\text { mixed with water }\end{array}$ & Fluid is drunk \\
\hline $\begin{array}{l}\text { Terminalia schimperiana } \\
\text { Hochst. }\end{array}$ & roots & $\begin{array}{l}\text { Venereal } \\
\text { diseases such } \\
\text { as gonorrhea }\end{array}$ & $\begin{array}{l}\text { Roots boiled with } \\
\text { potassium }\end{array}$ & Fluid is drunk \\
\hline $\begin{array}{l}\text { Vitellaria paradoxa } \\
\text { C.F. Gaertn. }\end{array}$ & $\begin{array}{l}\text { seed, } \\
\text { bark }\end{array}$ & $\begin{array}{l}\text { Dislocation, } \\
\text { body pain, } \\
\text { stomachache, } \\
\text { dysentery }\end{array}$ & $\begin{array}{l}\text { Seed processed into } \\
\text { cream. Bark cooked } \\
\text { as concoction. }\end{array}$ & $\begin{array}{l}\text { Cream used to } \\
\text { massage affected area. } \\
\text { Concoction drunk }\end{array}$ \\
\hline Vitex doniana Sweet & $\begin{array}{l}\text { leaf, } \\
\text { bark }\end{array}$ & Stomachache & $\begin{array}{l}\text { Leaves and bark } \\
\text { boiled together }\end{array}$ & Fluid is drunk \\
\hline
\end{tabular}

* Alligator pepper (Aframomum melegueta K. Schum.)

We examined the relationship between usefulness of a plant and its mean density. Simple linear regressions were done of usefulness against density rank. Use value was calculated by adding up number of uses of a species (Boom 1990). Uses were hierarchically ordered. Thus, uses in each category and multiple uses (uses in more than one category) were treated separately. The analysis was done using Statistical Package for Social Sciences (SPSS 2001).

\section{Results}

\section{Utilization categories of selected plant species}

Family distribution of selected species shows that Fabaceae was the most dominant family in terms of number of species represented. This was followed by Combreta- ceae, Malvaceae and Rubiaceae in that order. Most of these species have multiple uses, an observation similar to the report of Kala (2005) and Akinsoji (2003). Among the plant-use categories, medicinal uses rank the highest $(38 \%)$ followed by edible plants $(25 \%)$ and miscellaneous purposes $(24 \%)$. Plants used for construction purposes occupy $13 \%$ of use categories.

\section{Medicinal plants}

Information on the medicinal plants of Kainji Lake National Park is presented in Table 3. This includes; local names, types of ailments treated, parts of plant used, preparations and administration procedures. About twenty-seven (27) ailments were recorded. Of striking note is the use of Crossopteryx febrifuga (Afzel. ex G. Don) Benth. for the revival of dying domestic animals. Most plants are used 
for treating more than one ailment, while preparations often involve the inclusion of ancillary items such as alligator pepper (Aframomum melegueta K. Schum.), potash and ginger (Zingiber officinale Roscoe). The most widely used parts of the plants in this region are the bark, followed by the leaves and roots. Seeds and fruits are not commonly used in preparations of decoctions for treating ailments. The mode of administration ranges from drinking or bathing with the preparations, chewing and sitting atop the prescription among others.

\section{Edible plants}

Table 4 reveals that some of the identified plants of Kainji Lake National Park are used as food items by local people. Nineteen (19) of 37 species discussed in this study are eaten. The most widely consumed parts of the plants are the fruits. For example, the leaves of Adansonia digitata L. are ground into a powdery form to prepare a locally popular soup called kuka. Parkia biglobosa (Jacq.) R. Br. ex G. Don, Cochlospermum tinctorium A. Rich. and Vitellaria paradoxa C.F. Gaertn., are used as additives, spices and a cooking oil source respectively. Some fruits such as Vitex doniana Sweet, Diospyros mespiliformis Hochst. ex A. DC., Parkia biglobosa (Jacq.) R. Br. ex G. Don and Vitellaria paradoxa C.F. Gaertn. are harvested and sold in the market mostly by women and children to augment family income.

\section{Plants used for construction purposes}

From Table 5, ten (10) plant species out of the 37 studies from Kainji Lake National Park are used for construcNational Park, Nigeria.
Table 4. Edible plants in the Borgu Sector of Kainji Lake National Park, Nigeria.

\begin{tabular}{|l|c|c|c|c|c|}
\hline \multirow{2}{*}{ Species } & \multicolumn{3}{|c|}{ Parts of plant eaten } \\
\cline { 2 - 6 } & Leaf & Fruit & Seed & Bark & Root \\
\hline Adansonia digitata L. & L & F & & & \\
\hline Afzelia africana Sm. & & & S & & \\
\hline Annona senegalensis Pers. & & F & & & \\
\hline Bridelia ferruginea Benth. & & & S & & \\
\hline Cochlospermum tinctorium A. Rich. & & & & & R \\
\hline Combretum molle R. Br. ex G. Don & & & S & & \\
\hline Combretum nigricans Lepr. ex Guill. \& Perr. & L & & & & \\
\hline Detarium microcarpum Guill. \& Perr. & & F & & & \\
\hline Diospyros mespiliformis Hochst. ex A. DC. & & F & & & \\
\hline Gardenia aqualla Stapf \& Hutch. & & F & & & \\
\hline Nauclea latifolia Sm. & & F & & & \\
\hline Parkia biglobosa (Jacq.) R. Br. ex G. Don & & F & S & & \\
\hline Prosopis africana (Guill. \& Perr.) Taub. & & F & & & \\
\hline Sterculia setigera Delile & & F & & & \\
\hline Strychnos spinosa Lam. & & F & & & \\
\hline Terminalia macroptera Guill. \& Perr. & & F & S & & \\
\hline Vitellaria paradoxa C.F. Gaertn. & & F & S & & \\
\hline Vitex doniana Sweet & & F & & & \\
\hline Ximenia americana L. & & & \\
\hline
\end{tabular}

Table 5. Plants used for construction purposes in the Borgu Sector of Kainji Lake

\begin{tabular}{|l|l|c|c|}
\hline Species & Part used & \multicolumn{2}{|c|}{ Purpose } \\
\cline { 3 - 4 } & & Timber & Rope \\
\hline Acacia seyal Delile & bark & & $\mathbf{R}$ \\
\hline Afzelia africana Sm. & wood & $\mathbf{T}$ & \\
\hline Anogeissus leiocarpus (DC.) Guill. \& Perr. & wood, stem & $\mathbf{T}$ & \\
\hline Burkea africana Hook. & wood & $\mathbf{T}$ & \\
\hline Cochlospermum tinctorium A. Rich. & stem & & $\mathbf{R}$ \\
\hline Daniellia oliveri (Rolfe) Hutch. \& Dalziel & wood & $\mathbf{T}$ & \\
\hline Isoberlinia doka Craib \& Stapf & wood & $\mathbf{T}$ & \\
\hline Khaya senegalensis (Desr.) A. Juss. & wood & $\mathbf{T}$ & \\
\hline $\begin{array}{l}\text { Piliostigma thonningii (Schumach.\& } \\
\text { Thonn.) Milne-Redh. }\end{array}$ & bark & & $\mathbf{R}$ \\
\hline Vitex doniana Sweet & & & \\
\hline
\end{tabular}

tion purposes. The most common part used is wood. The bark of Piliostigma thonningii (Schumach.\& Thonn.) Milne-Redh. is used as rope to tie farm products and to tie pieces of wood together for roofing. Plants like Isoberlinia doka Craib \& Stapf, Daniellia oliveri (Rolfe) Hutch. \& Dalziel and Khaya senegalensis (Desr.) A. Juss. are used 


\section{Amusa et al. - Ethnobotany and Conservation of Plant Resources of Kainji Lake National Park, Nigeria}

Table 6. Miscellaneous uses of plants in the Borgu Sector of Kainji Lake National Park, Nigeria.

\begin{tabular}{|l|l|c|c|c|c|c|}
\hline \multirow{2}{*}{ Species } & Parts Used & \multicolumn{3}{|c|}{ Uses } \\
\cline { 4 - 7 } & & Shade & $\begin{array}{l}\text { Chewing } \\
\text { stick }\end{array}$ & Ink & Potash & $\begin{array}{c}\text { Fuel } \\
\text { wood }\end{array}$ \\
\hline Acacia seyal Delile & stem & & & & & FW \\
\hline Afzelia africana Sm. & wood, canopy & S & & & & FW \\
\hline $\begin{array}{l}\text { Anogeissus leiocarpus (DC.) Guill. } \\
\text { \& Perr. }\end{array}$ & $\begin{array}{l}\text { wood, } \\
\text { branches }\end{array}$ & & & & & FW \\
\hline Burkea africana Hook. & $\begin{array}{l}\text { wood, } \\
\text { branches }\end{array}$ & & & & & FW \\
\hline $\begin{array}{l}\text { Crossopteryx febrifuga (Afzel.ex G. Don) } \\
\text { Benth. }\end{array}$ & wood & & CS & & & \\
\hline Daniellia oliveri (Rolfe) Hutch. \& Dalziel & wood & S & & & & FW \\
\hline Detarium microcarpum Guill. \& Perr. & $\begin{array}{l}\text { branches, } \\
\text { stem }\end{array}$ & & & & & FW \\
\hline $\begin{array}{l}\text { Diospyros mespiliformis Hochst. } \\
\text { ex A. DC. }\end{array}$ & stem & & CS & & & \\
\hline Isoberlinia doka Craib \& Stapf & wood, canopy & S & & & & FW \\
\hline Khaya senegalensis (Desr.) A. Juss. & wood & S & & & & FW \\
\hline Lannea acida A. Rich. & whole plant & S & & & & FW \\
\hline Parinari polyandra Benth. & wood & & & & & FW \\
\hline $\begin{array}{l}\text { Piliostigma thonningii (Schumach.\& } \\
\text { Thonn.) Milne-Redh. }\end{array}$ & stem & & & & & FW \\
\hline Prosopis africana (Guill. \& Perr.) Taub. & stem & & CS & & & \\
\hline Terminalia macroptera Guill. \& Perr. & stem, wood & & CS & & P & \\
\hline Vitex doniana Sweet & wood & & & I & & \\
\hline
\end{tabular}

as timber in furniture and household items such as chairs, benches, stools, mortars and pestles.

\section{Plants used for miscellaneous purposes}

Several plants of Kainji Lake National Park still serve some other purposes that are crucial to human survival (Table 6). Most plants are used as fuel-wood for household energy generation. This also serves as a means of generating income to fuel-wood marketers. The matured fruits of $V$. doniana are also used as ink by extracting the juice from the fruits. T. macroptera is also reputed to be the best in potash production among the local communities.

\section{Status of woody plants in the Borgu Sector of Kainji Lake National Park}

Table 7 shows the mean relative frequency and population density of plants in the study area. Detarium microcarpum has the highest mean frequency represented with $68.9 \%$ and a population density of $3.036 \pm 1.7$ individuals/ ha. This is followed by $V$. paradoxa with $55.6 \%$ mean frequency and a population density of $2.1 \pm 1.7$ individuals/ ha. The plant with the least mean frequency is Kigelia afri- cana (Lam.) Benth. with $5.3 \%$ and a population density of $0.004 \pm 0.3$ individuals/ha.

\section{Abundance Classification Scheme for Plants In Borgu Sector Of Kainji Lake National Park}

The abundance classification scheme presented in table 8 indicates that, out of the thirtyseven (37) plants, only three (3) species fall in the very abundant category. Two (2) species are categorized as simply abundant while thirteen (13) and twelve (12) others fall in the frequent and occasional category respectively. Similarly, five (5) species are rated as rare and two (2) are very rare.

\section{Regression Analysis of Relationship between Plant usefulness and density rank}

The model summary data is presented in Table 9 . The $R$ value of 0.047 for the multiple correlation coefficient indicates a weak relationship between the predictor variable (density rank) and the dependent variable (usefulness). $R^{2}(0.002)$ coefficient of determination, shows that an insignificant proportion of the variation observed is explained by the model. The significance value of the $F$ sta- 
Table 7. Mean relative frequency and population density of plants in the Borgu Sector of Kainji Lake National Park, Nigeria.

\begin{tabular}{|c|c|c|c|}
\hline Species & $\begin{array}{c}\text { Relative } \\
\text { Frequency (\%) }\end{array}$ & $\begin{array}{l}\text { Mean Density } \\
\text { (Individual /ha) }\end{array}$ & Density Rank \\
\hline Acacia seyal Delile & 20.11 & $0.018 \pm 0.053$ & 29 \\
\hline Adansonia digitata L. & 12.08 & $0.002 \pm 0.190$ & 35 \\
\hline Afzelia africana $\mathrm{Sm}$. & 25.43 & $0.089 \pm 0.560$ & 17 \\
\hline Annona senegalensis Pers. & 34.99 & $0.893 \pm 1.140$ & 9 \\
\hline Anogeissus leiocarpus (DC.) Guill. \& Perr. & 32.57 & $0.179 \pm 0.400$ & 13 \\
\hline Boswellia dalzielii Hutch. & 16.53 & $0.011 \pm 0.053$ & 31 \\
\hline Bridelia ferruginea Benth. & 32.85 & $0.257 \pm 0.720$ & 12 \\
\hline Burkea africana Hook. & 43.01 & $1.607 \pm 0.910$ & 4 \\
\hline Combretum molle R. Br. ex G. Don & 53.89 & $1.786 \pm 1.200$ & 3 \\
\hline Combretum nigricans Lepr. ex Guill. \& Perr. & 41.20 & $1.429 \pm 0.360$ & 6 \\
\hline Cochlospermum tinctorium A. Rich. & 41.70 & $1.543 \pm 0.640$ & 5 \\
\hline Crossopteryx febrifuga (Afzel.ex G. Don) Benth. & 31.51 & $0.125 \pm 0.600$ & 15 \\
\hline Daniellia oliveri (Rolfe) Hutch. \& Dalziel & 21.94 & $0.026 \pm 1.930$ & 22 \\
\hline Detarium microcarpum Guill. \& Perr. & 68.89 & $3.036 \pm 1.680$ & 1 \\
\hline Diospyros mespiliformis Hochst. ex A. DC. & 33.00 & $0.036 \pm 2.960$ & 20 \\
\hline Entada africana Guill. \& Perr. & 20.47 & $0.019 \pm 0.220$ & 27 \\
\hline Gardenia aqualla Stapf \& Hutch. & 24.68 & $0.054 \pm 1.030$ & 19 \\
\hline Grewia mollis Juss. & 32.23 & $0.161 \pm 0.670$ & 14 \\
\hline Isoberlinia doka Craib \& Stapf & 16.10 & $0.009 \pm 0.680$ & 33 \\
\hline Khaya senegalensis (Desr.) A. Juss. & 18.15 & $0.016 \pm 0.210$ & 30 \\
\hline Kigelia africana (Lam.) Benth. & 5.30 & $0.004 \pm 0.230$ & 37 \\
\hline Lannea acida A. Rich. & 20.24 & $0.019 \pm 1.100$ & 28 \\
\hline Maytenus senegalensis (Lam.) Exell & 38.86 & $1.250 \pm 2.010$ & 7 \\
\hline Nauclea latifolia Sm. & 25.42 & $0.071 \pm 0.090$ & 18 \\
\hline Parinari polyandra Benth. & 16.15 & $0.010 \pm 0.087$ & 32 \\
\hline Parkia biglobosa (Jacq.) R. Br. ex G. Don & 37.10 & $1.071 \pm 0.190$ & 8 \\
\hline Piliostigma thonningii (Schumach.\& Thonn.) Milne-Redh. & 32.92 & $0.536 \pm 0.570$ & 11 \\
\hline Pterocarpus erinaceus Poir. & 20.72 & $0.020 \pm 0.000$ & 26 \\
\hline Prosopis africana (Guill. \& Perr.) Taub. & 21.83 & $0.025 \pm 0.560$ & 24 \\
\hline Sterculia setigera Delile & 13.59 & $0.005 \pm 0.070$ & 34 \\
\hline Strychnos spinosa Lam. & 33.93 & $0.714 \pm 0.970$ & 10 \\
\hline Tamarindus indica L. & 21.85 & $0.025 \pm 0.410$ & 23 \\
\hline Terminalia macroptera Guill. \& Perr. & 21.08 & $0.022 \pm 0.510$ & 25 \\
\hline Terminalia schimperiana Hochst. & 28.23 & $0.107 \pm 2.680$ & 16 \\
\hline Vitellaria paradoxa C.F. Gaertn. & 55.58 & $2.143 \pm 1.670$ & 2 \\
\hline Vitex doniana Sweet & 22.26 & $0.028 \pm 0.520$ & 21 \\
\hline Ximenia americana L. & 7.46 & $0.014 \pm 0.890$ & 36 \\
\hline
\end{tabular}




\section{Amusa et al. - Ethnobotany and Conservation of Plant Resources of Kainji Lake National Park, Nigeria}

Table 8. Abundance classification scheme for plants in Borgu Sector of Kainji Lake National Park, Nigeria.

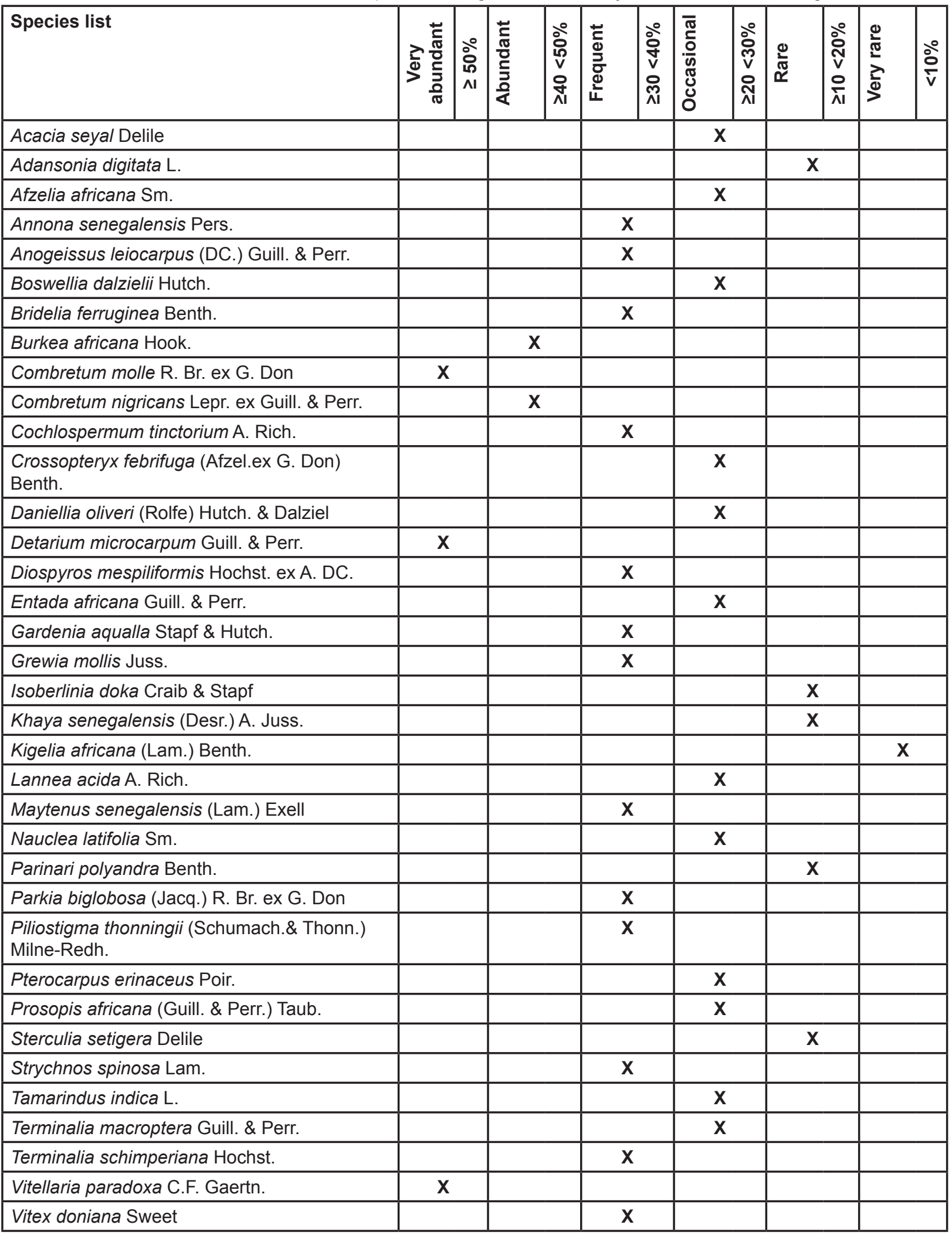


Table 9. Model summary for plants used in the Borgu Sector of Kainji Lake National Park, Nigeria.

\begin{tabular}{|c|c|c|c|c|c|c|c|c|c|c|}
\hline \multirow[t]{2}{*}{ Model } & \multirow[t]{2}{*}{$\mathrm{R}$} & \multirow{2}{*}{$\begin{array}{l}\mathrm{R} \\
\text { Square }\end{array}$} & \multirow{2}{*}{$\begin{array}{l}\text { R Square } \\
\text { Adjusted }\end{array}$} & \multirow{2}{*}{$\begin{array}{l}\text { Std. Error } \\
\text { of the } \\
\text { Etimate }\end{array}$} & \multicolumn{5}{|c|}{ Change Statistics } & \multirow{2}{*}{$\begin{array}{l}\text { Durbin- } \\
\text { Watson }\end{array}$} \\
\hline & & & & & $\begin{array}{l}\text { R Square } \\
\text { Change }\end{array}$ & $\begin{array}{l}\mathrm{F} \\
\text { Change }\end{array}$ & df1 & $\mathrm{df} 2$ & $\begin{array}{l}\text { Sig. F } \\
\text { Change }\end{array}$ & \\
\hline 1 & .047 & .002 & -.026 & 1.44020 & .002 & .077 & 1 & 35 & .783 & 1.653 \\
\hline
\end{tabular}

a. Predictors: (Constant), VAR00001

b. Dependent Variable: VAR00002

tistic $(0.783)$ is greater than 0.05 , which means that the variation explained by the model is due to chance.

\section{Discussion}

Many studies have analyzed indigenous knowledge of plant use among different communities (e.g., Kala 2005, Rijal 2008). In this study, indigenous communities living in the support zones of Kainji Lake National Park have learned to utilize the resources around them in many ways. Four categories of use were identified viz; food, medicine, construction and miscellaneous.

\section{Ethnomedicinal knowledge of plants}

The study reveals that medicinal plants account for a larger proportion of respondents' dependence on the protected area. This could be attributed to the fact that the primary occupation in the study area is agriculture, largely farming activities which in effect reduced the need for forest foods. As noted by Kiringe (2005), use of traditional medicine is prevalent among rural communities of Africa. They have immense knowledge on ethnomedicine, although its use is rapidly diminishing partly due to lifestyle changes and exposure to Western ideologies. Twenty-seven ailments from thirty species have been documented in this study, with some species overlapping in the treatment of the same ailment. This observation is similar to the reports of Kala on traditional knowledge systems of plants in India (Kala 2005). Generally, several factors persist to account for dependency on traditional medicine. Traditional medicine unlike modern medicine is an integral component of many cultures which has evolved for many generations, and it is considered effective in treating and managing certain cultural health problems (Sindiga 1994). It is also considered efficacious, readily acceptable by the community and as well holistic in its approach to addressing health problems. Further, it is cost effective and traditional healers charge affordable fees. It is also readily available and accessible to rural communities even where infrastructure is poor (Phillips 1985, Pillsbury 1979, Sindiga 1994, WHO 1978). Dependence on traditional medicine can also be attributed to a strong attachment to traditional lifestyle, high level of poverty in the community, remoteness of area coupled by very poor infra-structure which makes access to modern health facilities difficult. Also, most rural communities of Africa do not see any danger associated with the use of herbal remedies. In fact, initial home treatment of sick persons using herbal remedies is a common practice among African communities (Brown 1995, Iwu 1993, Sindiga et al. 1995). The mention of C. febrifuga for the revival of dying domestic animals in this study shows the intricate skills and knowledge communities have acquired in the use of plant resources.

Meanwhile, some of the medicinal plants in this study are considered occasional and rare (Table 8). This raises concern about the need for both short and long term intervention strategies to save the species into the future. There is indeed an urgent need for an official policy for developing and upgrading local plants used as source of medicines to complement orthodox therapy in Nigeria. More so, over $80 \%$ of Nigerians are reported to depend on herbal medicines (Ugbogu 2005), while modern healthcare is still beyond the reach of a good proportion of the rural population.

\section{Plants used for food, construction and miscellaneous purposes}

The use values of the studied species transcend medicinal importance. Large quantities of the species are also utilized for food, construction, fuelwood and miscellaneous purposes such as ink, potash and chewing sticks. Over exploitation and commercial sale of some of the species is already threatening the long term availability of a significant portion of such species, particularly $D$. microcarpum and $V$. paradoxa both of which are valued for firewood and charcoal purposes. Interestingly, these two species are still in abundance and have the highest density ranks and mean frequencies among studied species (Table 7). Nevertheless, an increasing number of reports have documented the over-harvest of non-timber forest products (NTFPs) and the negative effects on plant and animal populations in many nature reserves (Bhatnagar 2002, Shahabuddin \& Prasad 2004, Ticktin 2004). It is therefore, imperative that the extent and impacts of exploitation of these species be studied to elucidate the need for enhanced conservation and also to guarantee the livelihoods of the people. Further, the development of these groups of plants could serve as a basis for the implementation of a program aimed at encouraging local community involvement in the protection and management of the park. This is more important given the fact that the buffer zone of the park is seriously being encroached into by local communities and other settlers from neighbouring States. 


\section{Amusa et al. - Ethnobotany and Conservation of Plant Resources of Kainji Lake National Park, Nigeria}

\section{Status of selected plant species}

In terms of species density and abundance, only three species consisting of Combretum molle R. Br. ex G. Don, $D$. microcarpum and $V$. paradoxa ranked high and very abundant ( $\geq 50 \%$ in occurrence). Closely following these species are Burkea africana Hook. and Combretum nigricans Lepr. ex Guill. \& Perr., which are classified as simply abundant $(\geq 40 \%<50 \%)$. Other species are poorly represented. However, there was no significant relationship between the useful value of a species and its density rank. This observation tends to suggest that exploitation is not the only key threat to continued availability of a species. Indeed, studies have indicated that the effects of harvest on both individuals and populations of a given species are highly variable and are mediated by different sources of variation including: variation in plant part and life history; variation in environmental conditions; variation due to management; variation in harvest method and; variation in land-use context (Siebert 2004, Ticktin 2004).

Extraction of certain species of plants from protected areas has been viewed as a conservation strategy based on the argument that forest conservation must be able to offer economic incentives to local rural people to counter the threat from destructive land uses such as logging and cattle ranching (Ticktin 2004). It has also been reported that local people not only exploit their bio-resources for meeting basic needs, but are also aware of the consequences of ruthless exploitation and have thus evolved their own means of sustainable exploitation of these resources (Bish et al. 2006). However, up scaling demand for plant raw material coupled with handsome incentives associated with increased extraction might lead to over exploitation of the same resources for short-term gain.

\section{Conclusion}

Communities living at forest margins and other woodland areas use forest resources in various ways. Understanding the resource-use patterns of such communities provides a basis for seeking their participation in forest and woodland conservation. Given the preceeding findings of this study, it is clear that the protection of biodiversity, which is one of the management objectives of the KLNP, will not be best achieved by precluding the local communities. In essence, embracing the paradigm shift of participatory management and integrating the aspirations of the local populace to the very existence of the Park will be a more effective way of enlisting their support in biodiversity management and protection. Furthermore, there is the need to devise sustainable harvesting techniques for wild populations of plant species from buffer zone areas in order to address the demand of the local people. Indeed, giving stewardship of natural resources to local people and encouraging profitable uses of those resources may provide a powerful incentive for conservation. Although, we did not establish any correlation between the useful value of a species and its density rank, it will not be out of place on the part of government and Park management authority to establish woodlots and arboreta for the supply of fuel wood and deliberate cultivation of medicinal plants and other non-timber forest products in need by the support zone communities. Sustainable harvesting combined with cultivation can help improve yields of harvested species in buffer zones, and it may reduce pressure on protected areas.

\section{Acknowledgement}

The authors are indeed thankful to the anonymous reviewers for their useful and insightful comments. We are also grateful to authorities of the KLNP and members of its support zone communities.

\section{Literature Cited}

Adeola, A.O., I.O.O. Aiyelaagbe, D.O. Ladipo \& L. Popoola. 1994. Survey of multipurpose tree species for prioritisation in the humid lowland of Nigeria. Report to ICRAF, February 1994.

Akinsoji, A. 2003. Vegetation studies of Gashaka Gumti National Park: An ethnobotany. The Nigerian Field 68(2):124-44.

Benz, B., J. Cevallos, F. Santana \& S. Graf. 2000. Loosing knowledge about plant use in the Sierra de Manantlan Biosphere Reserve, Mexico. Economic Botany 54:183191.

Bhatnagar, P. 2002. Conservation and trade of medicinal herbs: A study of Safed Musli (Chlorophytum spp.) in Madhya Pradesh. Sustainable Forestry 7:11-14.

Bisht, A.K., A. Bhatt, R.S. Rawal+\& U. Dhar. 2006. Prioritization and conservation of Himalayan medicinal plants: Angelica glauca Edgew. as a case study. Ethnobotany Research \& Applications 4:011-023 .

Boom, B.M. 1990. Useful plants of the Panare Indians of the Venezuelan Guayana. Advances in Economic Botany 8:57-76

Brown, K. 1995. Medicinal plants, indigenous medicine and conservation of biodiversity in Ghana. Pp. 201-231 in Intellectual Property Rights and Biodiversity Conservation. Edited by T. Swanson. Cambridge University Press, London.

Byers, B.A., R.N. Cunliffe \& A.T. Hudak. 2001. Linking the conservation of culture and nature: A case study of sacred forests in Zimbabwe. Human Ecology 29:187-218. 
Child, G.S. 1974. An Ecological Survey of the Borgu Game reserve. Kainji Lake. Research Project, Nigeria. United Nations Development Project FI Technical Report. No 4. F.1: SF/NIR. 24. Food and Agriculture Organization, Rome.

Connie, V. \& R.K. Steven. 2005. An introduction to ethnobotany. An African Ethnobotany. Bulletin No. 2.

CBD. 1992. Traditional Knowledge and the Convention on Biological Diversity.www.cbd.int/traditional/intro.shtml Retrieved on 28th July, 2008.

DRB. 2004. Ecological Survey of Kainji Lake National Park. Consultancy report submitted by the Development Research Bureau to the Project Preparation Manager, Global Environmental Fund- Local Empowerment \& Environmental Management Project, Asokoro District, Abuja.

Freudenthal, S. \& J. Narrowe. 1991. Focus on People and Trees. A guide to designing and conducting baseline studies for community forestry. Minor Field Studies No. 47. Swedish University of Agricultural Sciences. International Rural Development Centre. Uppsala.

Iwu, M.I. 1993. Handbook of African Medicinal Plants. CRC Press, Boca Rotan, Florida.

Kala, C.P. 2005. Indigenous uses, population density and conservation of threatened medicinal plants in protected areas of the Indian Himalayas. Conservation Biology 19:368-378.

Kiringe, J.W. 2005. Ecological and anthropological threats to ethno-medicinal plant resources and their utilization in Maasai communal ranches in the Amboseli region of $\mathrm{Ke}$ nya. Ethnobotany Research \& Applications 3:231-241.

McCracken, J.A., J.N. Pretty \& G.R. Conway. 1998. An Introduction to Rapid Rural Appraisal for Agricultural Development. International Institute for Environment and Development, London.

Milligan, K. 1979. An Ecological Basis for the Management of Kainji Lake National Park (KLNP). Ph.D Thesis. University of Ibadan, Ibadan.

Phillip, O.L. \& A.H. Gentry. 1993. The useful plants of Tamborata, Peru I: Statistical hypothesis tests with new quantitative techniques. Economic Botany 47:15-32.

Phillips, D.R. 1985. Directions for medical geography in the 1980s: Some observations from the United Kingdom. Social Science and Medicine 20:404-407.

Pillsbury, B.L.K. 1979. Reaching the Rural Poor: Indigenous health practitioners are there already. AID Program
Evaluation Discussion Paper Series No. 1. USAID, Washington, D.C.

Plotkin, M.J. 2006. Ethnobotany. Microsoft Encarta, Microsoft, Redmond, Washington.

Rijal, A. 2008. A quantitative assessment of indigenous plant uses among two Chepang communities in the Central Mid-hills of Nepal. Ethnobotany Research \& Applications 6:395-404.

Shahabuddin, G. \& S. Prasad. 2004. Assessing ecological sustainability of non-timber forest produce extraction: The Indian scenario. Conservation \& Society 2:235-250.

Sidinga, I. 1994. Indigenous medical knowledge of the Maasai. Indigenous Knowledge and Development Monitor 2:16-18.

Sindiga, I. 1995. Traditional medicine in Africa: An introduction. Pp. 1-15 in Traditional Medicine in Africa. Edited by I. Sindiga, C. Nyaigotti-Chacha \& M.P. Kanunah. East African Educational Publishers Ltd., Nairobi.

Siebert, S.E. 2004. Demographic effects of collecting rattan cane and their implications for sustainable harvesting. Conservation Biology 18:424-431.

SPSS. 2001. Statistical Package for Social Sciences. SPSS for Windows, Rel. 11.0.1. 2001. Chicago: SPSS Inc.

Ticktin, T. 2004. The ecological implications of harvesting non-timber forest products. Journal of Applied Ecology 41:11-21.

Tuna Wildlife Consultants and NARDES 1983. A Master Plan for the Management of Kainji Lake National Park. Consultancy Report Submitted to the Kainji Lake National Park Board, New Bussa, Nigeria.

Twarog, S. \& P. Kapoor. 2004. Editors of Protecting and Promoting Traditional Knowledge: Systems, national experiences and international dimensions. United Nations Conference on Trade and Development (UNCTAD). United Nations, New York and Geneva.

Ugbogu, O.A. 2005. Medicinal plants used by the Okpameri people in Edo State. The Nigerian Field 70:125-136.

WHO. 1978. The Promotion and Development of Traditional Medicine. Report of World Health Organization meeting No. 622. World Health Organization, Geneva. 